\title{
Impact of Organic Nutrient Management on Crop Quality, Yield and Soil Health: A Review
}

\author{
Santosh Onte, Magan Singh*, Sanjeev Kumar and Prasanna S. Pyati \\ Agronomy Division, ICAR-National Dairy Research Institute, Karnal-132001, India \\ *Corresponding author
}

\section{A B S T R A C T}

\section{Keywords \\ Organic nutrients, Yield, Quality, Soil property, Banana Pseudostem, Panchagavya \\ Article Info \\ Accepted: \\ 04 April 2019 \\ Available Online: \\ 10 May 2019}

\begin{abstract}
Organic nutrients are proven things that improving crop productivity, quality and yield which in turn enhance the quality and richness of the soil properties and make way for the healthier environment for the beneficial soil micro-organism. The organic nutrients which are interfered with healthier agriculture for the betterment of life; the organic nutrient source which are liquid biofertilizer, farm yard manure, vermicompost, banana pseudostem sap, panchagavya, beejamrut, amritpani etc which are playing very important role in the healthier crop production system. Organic nutrients are nutritionally rich and biologically and environmental friendly one and sustainable. Many agricultural practices and synthetic agro-chemicals risked the soil fertility and spoiling the eternity of the nature. Not only the organic nutrient enhances the quality and yield which also enhances the life span of the nature and its entities. Many researchers are confirmed the better results of the organic nutrients and its effect on the agriculture and horticulture crops. To fulfill the biologically and economically sound practices in agriculture system there is a need of inclusion of organic component in the present farming practices.
\end{abstract}

\section{Introduction}

Organic farming is an age old traditional practice evolved by our fore fathers wherein only organic manures or natural inputs available on the farm are used thus reduces the cost of production against chemical inputs. Organic Agriculture is a production system that sustains the health of soils, ecosystems and people. It relies on ecological processes, biodiversity and cycles adapted to local conditions, rather than the use of inputs with adverse effects (IFOAM). General acceptance of organic farming is not only due to the greater demand for pollution-free food but also due to natural advantage of organic farming in supporting the sustainability in agriculture. The natural inputs used in organic farming are easily available, releases nutrients slowly, supplies macro and micro nutrients and provides favourable soil environment for microbial population (Shashidhara, 2000; Devakumar et al., 2011).

Imbalanced and unscientific use of agricultural chemicals viz., fertilizer and synthetic pesticides resulted in unhealthy soil; ultimately which affects the quality of farm 
produce. Farm produces with unwarranted chemicals are considered to be harmful to consumer's health. Increasing awareness about devastating impact of agricultural chemicals on environment, stringent rules and regulations of food safety and deadly effect on human wellbeing compelled to raise the crops devoid of these dangerous chemicals. Under such circumstances when demand of higher quality food is increasing day by day, crops which are raised with eco-friendly techniques are one of the potential options. This can be achieved by adopting organic farming practices. The demand of quality and health friendly organic product has also been increasing and now it become more popular and also sold at a premium prices in domestic and foreign market.

For successful organic farming in any crops depends upon the availability of nutrients at right time and in right amount, particularly in short duration crops. If nutrient supply is not matching with the requirements then crop production is adversely affected. The availability of nutrients from organic manures is depending upon the $\mathrm{C}: \mathrm{N}$ ratio of the manures. Wider the $\mathrm{C}: \mathrm{N}$ ratio, slower the nutrient release and sometime immobilization is occurred. Therefore, integration of different organic manures to narrow the $\mathrm{C}: \mathrm{N}$ ratio can increase the rate of decomposition and speedup the nutrient release. India is known for higher sugarcane production therefore, number of sugar factories is working in this area and produce biocompost as byproduct. Vermicompost and FYM are widely used organic manures. When these manures mix with concentrate viz., castor or neem cake having higher content of $\mathrm{N}$, releases the available nutrient particularly $\mathrm{N}$ at faster rate. Numbers of experiments were conducted on this line and the results of these experiments indicated that through integration of these manures achieved the yield equivalent to chemical fertilizers (Anon., 2011b). Organic manures are slow release natural fertilizers and also improve the nutrient use efficiency and quality of the crops. Apart from these, it improves the soil physical conditions which are more desirable for tuber crops like onion and more so under high clay containing soils.

It is well known that banana is the heavy feeder crop of nutrients. After harvest of banana, remaining plant parts treated as waste. This contain high amount of essential plant nutrients, which is being lost. By utilizing such waste plant material, many useful by-products like fibre, paper, fabrics, organic manure etc. can be prepared. While separating fibers from the banana pseudostem, the liquid available is known as sap which contains good amount of essential macro and micronutrients as well as growth boosters. Salunkhe (2010) analysed the samples of banana pseudostem for its elemental composition and found that banana pseudostem contained macro elements in the range of 1.00 to $1.12 \% \mathrm{~N}, 0.50$ to $0.71 \% \mathrm{P}$, 2.39 to $20.2 \% \mathrm{~K}$ and micro nutrients in the range of 259 to $323.2 \mathrm{mg} / \mathrm{kg} \mathrm{Fe}, 47.3$ to 241.3 $\mathrm{mg} / \mathrm{kg} \mathrm{Mn}, 10.1$ to $107.4 \mathrm{mg} / \mathrm{kg} \mathrm{Zn}$ and 13.4 to $83.6 \mathrm{mg} / \mathrm{kg} \mathrm{Cu}$.

Panchagavya, Jeevamrutha Amritpani are plant growth promoting substances containing beneficial microorganisms which promotes growth and yield of crop. Micro-organisms are well activated in the soil by the addition of jeevamrutha. The microorganisms such as nitrogen fixer, Azotobacter, Azospirillum and phosphorus solubilizing bacteria Pseudomonas fluorescence and potash solubilizing bacteria like Bacillus silicus are present in the cow dung that is used to prepare jeevamrutha (Ramprasad et al., 2009). Individual application of organic sources could not produce significant effect thus the diversification of organic sources of plant nutrients is becoming popular in these days. Use of farm yard manure and organic liquid 
formulations like Panchagavya, cow urine and jeevamruta are potential sources of organic nutrients. Hence, the present experiment was conducted to study the combined effect of FYM and jeevamrutha on growth and yield of fieldbean. Farm yard manure is a decomposed organic matter obtained by the action of microbial population in a warm and moist aerobic environment using cow dung, cow urine and other waste materials available from backyard cattle (Ramprasad et al., 2009). Farmyard manure is a rich source of nutrients having inherent ability to improve the soil health and aeration, water holding capacity and substrate for beneficial microbial population. Decomposition of farmyard manure by microorganism results in release of carbon dioxide, water and mineral plant nutrients such as nitrogen, phosphorus, potassium and micronutrients.

\section{Anti disease and microbial properties}

Many plants have been used because study of antioxidant and antimicrobial properties, phytochemical screening and analysis of sap extracted from banana (Musa acuminata) pseudostem, which are due to compounds synthesized in the secondary metabolism of the plant (Nagarajan et al., 2013).

Sampath Kumar et al., (2012) reported the antifungal and antibiotic activity of peel and pulp of fully ripe bananas and a fungicide in the peel and pulp of green fruits is active against a fungus disease of tomato plants.

Priya et al., (2014) reported the phytochemical screening and analysis of pseudostem sap indicated the presence of these carbohydrates, protein and phenolic compounds and the antimicrobial studies with different fungal and bacterial strains indicated the antimicrobial properties for the sap as well.

\section{Effect on yield and yield attribute}

The liquid organic manures contains small amount of nutrients and growth boosters. When it applied to the crops it removes the imbalances in terms of physical, chemical and physiological aspects and harmonizes the basic element which revitalizes the growth process (Natarajan, 2008). Application of soil + mine spoil + coir pith vermicompost (1:1:1) + RDF significantly enhanced plant height $(27.2 \mathrm{~cm})$, number of leaves (33.3), and yield per plant $(38.5 \mathrm{~g})$, as compared to mine spoil alone + RDF Thanunathan et al., (1997). application of $50 \% \mathrm{~N}$ through vermicompost $+50 \% \mathrm{~N}$ and $100 \% \mathrm{PK}$ (chemical fertilizer) with the combinations of Azospirillum significantly increases bulb yield of onion while combinations of these treatments with Azotobacter significantly increases plant height $(60.90 \mathrm{~cm})$, number of leaves per plant (16.19) and leaf area per plant $\left(781.55 \mathrm{~cm}^{2}\right)$ as compared to application of organic manures alone (FYM @ 20 t/ha, VC @ 5 t/ha and FYM @10 t/ha) Jayathilake et al., (2002). Higher pods per plant, seed yield and biological yield in the treatment application of farm compost@5t/ha + poultry manure@ 1t/ha as compared to control and application of farm compost @ 5t/ha + VC @ 1t/ha. They also found that spraying of biofertilizer + cow urine increase pods/plant, test weight and seed yield as compared to control and spraying of biofertilizer only, Abraham and Lal (2003). Somasundaram et al., (2003) application of panchagavya @3\% significantly increased grain yield (17.7 q/ha), number of seed per pod (12.1) and 100 grain weight $(4.0 \mathrm{~g})$ as compared to application of recommended dose of fertilizer. The higher plant height, number of leaves, leaf area, flowers per plant and weight of flower was observed in the treatment of vermiwash spray as compared to cow dung extract, cow urine and vermicast extract Sivasubramanian and Ganeshkumar (2004). The result revealed that the yield 
components viz., productive tillers/hill, panicle length, filled grain panicle, seed test weight, grain yield and straw yield were found significantly higher in the treatment of panchgavya spray @ 3\% Yadav and Christopher (2006). George et al., (2007) application of vermicompost @ 2.5 t/ha along with vermiwash 1:1 spray registered significantly maximum dry chilli yield of 2.99 t/ha and plant height of $78.1 \mathrm{~cm}$. soil application of bio-gas slurry from 3 milch animals with $3 \%$ foliar spray of panchagavya recorded significantly higher grain yield of maize, sunflower, green gram Somasundaram et al., (2007). Bindumathi Mohan (2008) observed maximum number of fruits per plant and yield per plant of brinjal in the treatment of bokashi@750 kg/ha while in tomato the number of fruits per plant and yield per plant was observed maximum in the treatment of Bokashi@ @ 1250 kg/ha. However, panchagavya was found the most cost effective as it recorded higher CBR followed by amrit pani and bokashi. Foliar spray of panchagavya@3\% in combination with any organic source increases growth and yield of Kalmegh (Andrographis panculata) as compared to application of organic sources alone. However, the highest yield was observed in the treatment of FYM+NPK+ Panchagavya Sanjutha et al., (2008), higher values of growth and yield parameter viz. plant height, leaf area index, dry matter production, number of flower per plant, number of pods per plant, number of filled grain per pod and grain yield were recorded in the treatment of $1 \%$ urea or $2 \%$ DAP spray followed by vermiwash spray at floral initiation and 15 days after flowering (Kumar et al., 2008).

Application of 33t FYM $+8 \mathrm{t}$ neem cake/ha significantly increases the grain yield (20.5 $\mathrm{q} / \mathrm{ha}$ ) and straw yield (24.5 q/ha) of soyabean. Whereas, the highest crude protein (19.3\%) observed in the treatment received the nutrients based on STCR target $25 \mathrm{q} / \mathrm{ha}$ (50:145:43 NPK kg/ha) Patil et al., (2008). Kagne et al., (2008) observed that application of vermicompost @ 2.5 t/ha along with seed treatment of Azospirillum and PSB enhanced the growth and quality of sorghum and produced highest seed yield (21.7 q/ha). application of $50 \% \mathrm{RDN}+50 \% \mathrm{~N}$ through FYM + VAM and PSB @ $12.5 \mathrm{~kg} / \mathrm{ha}+$ panchagavya @ 3\% spray recorded significantly higher number of branches/plant, number of fruits/plant, fruit length and fruit yield as compared to RDF. This treatment also registered highest B:C ratio Naidu et al., (2009). Venkatalakshmi et al., (2009) observed that foliar application of panchagavya@3\% significantly increased number of leaves, LAI, green leaf yield and dry matter yield of Amaranthus viride and also higher result indicated that when panchagavya applied @ 3\% and 6\% with seed soaking treatment recorded 11 and 9 t/ha green leaf yield. Application of FYM @ 6 t/ha + Rhizobium + PSM significantly increased plant height $(32.9 \mathrm{~cm})$, pod weight per plant (11.9), seed index (55.3 g) and yield (1278 kg/ha) Zalate and Padmani (2009). A field trial to study the effect of banana pseudostem sap and vermiwash on fruit setting in mango was conducted at NAU, Navsari during 2009 to 2011. There were seven treatments comprising of $1 \%$ foliar spray of banana pseudostem sap, enriched banana pseudostem sap, vermiwash and its combinations along with control, apply 4 sprays i.e. at the time of flowering and 25, 50 and $100 \%$ flower opening. They observed maximum fruit retention with the treatment of sap and vermiwash in 1:1 ratio as compared to control. However it was at par with the treatment of enriched sap alone and sap and vermiwash in 2:1 ratio (Anon, 2011b). Application of $100 \%$ RDF + panchagavya spray@2\% significantly increased the plant height $(131.7 \mathrm{~cm})$, fruit length $(21.8 \mathrm{~cm})$, fruit girth $(4.66 \mathrm{~cm})$, fruit weight $(13.9 \mathrm{~g} /$ fruit $)$, 
fruit yield (12.7 q/ha), dry matter production (5.9 g per plant) and number of branches (3.2 per plant) Vennila and Jayanthi (2010), Salunkhe (2010) revealed that the application of banana psuedostem sap @ 2000 1/ha through micro irrigation system increase the plant height, leaf area per plant, bulb weight, average bulb weight and dry matter yield of onion, foliar application of $6 \%$ cow urine followed by panchagavya $6 \%$ was found to be superior in increasing the auxin content and reducing activity of IAA oxidase enzyme in shoot tip of cotton. According to them this information becomes useful to increasing the number of branches and productivity of desi cotton Bais et al., (2010), Sritharan et al., (2010) application of panchagavya $4 \%$ foliar spray registered higher dry matter production of $73.1 \mathrm{~g} /$ plant followed by moringa $5 \%$ foliar spray recording yield of $70.0 \mathrm{~g} /$ plant, highest number of tubers (575000/ha) and tuber yield $(28.7 \mathrm{t} / \mathrm{ha})$ in the treatment of $3 \%$ spraying of panchagavya at 15 days interval as compared to $3 \%$ spraying of panchagavya Ravichandran et al., (2011). Higher number of leaves, leaf length, height of the plant and root length of rice Tharmaraj et al., (2011), An experiment on evaluation of banana pseudostem sap as liquid fertilizer through drip irrigation in Banana was conducted at Soil and Water Management Research Unit at NAU, Navsari. The result revealed that the higher fruit yield was recorded in the treatment, application of three litre pseudostem sap per plant $+80 \%$ of RDF. It was at par with the treatment, application of 4 litre pseudostem sap $+80 \%$ RDF and 4 litre pseudostem sap + $100 \%$ RDF. Treatment, 4 litre pseudostem sap + $100 \%$ RDF recorded significantly more number of fingers per bunch then the remaining treatments. Similar experiment was also conducted on sugarcane and recorded the yield level during first and second year ranging from 140 to $200 \mathrm{t} / \mathrm{ha}$. Through the treatment effect was not significant yet, numerically the cane yield was tended to increase with increase in level of sap application from 5000 1/ha to 15000 1/ha (Anon., 2011b), Application of biocompost @ $20 \mathrm{t} /$ ha to paddy recorded significantly higher yield attributes and yield of paddy and castor Virdia et al., (2011).

\section{Effect on nutrient content and uptake}

Somasundaram et al., (2007) soil application of bio-gas slurry from 3 milch animals along with $3 \%$ foliar spray of panchagavya recorded significantly higher $\mathrm{N}$ uptake by maize, sunflower and green gram, foliar spray of panchagavya @ 3\% in combination with any organic source increase content and uptake of $\mathrm{N}, \mathrm{P}$ and $\mathrm{K}$ by Kalmegh as compared to application of organic sources alone. However, the highest content and uptake of these nutrients were found in the treatment, FYM + NPK (75-75-50 kg/ha) + Panchagavya Sanjutha et al., (2008), similarly highest uptake of major and micronutrients by chili in the treatment $50 \% \mathrm{RDN}+50 \% \mathrm{~N}$ through FYM + BF + Panchagavya @ 3\% foliar spray Naidu et al., (2009), Venkataramana et al., (2010) foliar spray of vermiwash @ 200 mg/l significantly increases $\mathrm{N}, \mathrm{P}$ and $\mathrm{K}$ content in mulberry leaves, found higher content and uptake of $\mathrm{N}(0.84 \%$ $277.82 \mathrm{~kg} / \mathrm{ha}), \mathrm{P}(0.22 \% 64.27 \mathrm{~kg} / \mathrm{ha})$ and $\mathrm{K}$ $(0.88 \% 270.52 \mathrm{~kg} / \mathrm{ha})$ in the treatment of foliar application of humic acid @ 0.05\% as compared to foliar application of panchagavya (3 and $4 \%$ ), vermiwash (10 and $20 \%$ ), EM (1 and $2 \%$ ) (Sathish and Paramaguru, 2010).

\section{Effect on quality}

Paramasivam et al., (2006) reported that There was no significant improvement in oil and protein content in groundnut seed was observed when applied composted poultry manure, composted pressmud or vermicompost on $\mathrm{N}$ equivalent base alone but 
in combination with panchagavya spray @ 3 $\%$ the results were significantly improved the quality of groundnut similarly Somasundaram et al., (2007) reported that application of biogas slurry of 3 milch animal + spray of Panchgavya @3\% increase soluble protein content of 15.20, 15.93, $16.94 \mathrm{mg} / \mathrm{g}$ in maize, sunflower, green gram respectively while Sanjutha et al., (2008), observed that significantly the highest andrographolide content $(1.31 \%)$ and yield $(8.11 \mathrm{~kg} / \mathrm{ha})$ in the treatment of FYM @ 15 t/ha + RDF + panchgavya foliar application @ $3 \%$.

However, the higher content and yield of andrographolide among organic treatments was recorded in the treatment of FYM @ 5 t/ha + panchagavya foliar application @ $3 \%$ in kalmegh (Andrographis paniculata). Surekha et al., (2009) reported that organic treatment improves the cooking quality in terms of elongation ratio and nutritional quality in terms of $\mathrm{P}$ and $\mathrm{K}$ content in brown and white rice grown in kharif as compared to inorganic treatment. Both the treatments were on par with respect to hulling (\%), head rice recovery $(\%)$, length/breadth of seed, amylase $(\%)$ and protein $(\%)$.

Sritharan et al., (2010) reported that application of panchagavya $4 \%$ enhanced the quality parameters of black pepper like solasodine, ascorbic acid (34 mg/100g), TSS (9.2) and Total Fenolics $(0.697 \mathrm{mg} / \mathrm{g})$ content in fruit as compared to other bioregullators i.e. leaf extract of mukia, moringa, prosophis and root extract of withania, while foliar spray of vermiwash and cowdung each at 100, 150 and $200 \mathrm{mg} / \mathrm{l}$ on biochemical content of mulberry was studied and the result was found that significantly improvement in quality of mulberry fruit in terms of chlorophyll $\mathrm{a}$ and $\mathrm{b}$, protein and carbohydrate content when applied $200 \mathrm{mg} / \mathrm{l}$ vermiwash as compared to control Venkatarmana et al., (2010).

\section{Effect on soil physical and chemical properties}

A long term study was conducted by Surekha et al., (2009) and reported that improvement in physical properties of soil under organic treatment. The values of soil BD under inorganic and organic treatments were 1.48 and $1.30 \mathrm{~g} / \mathrm{cc}$, respectively. Whereas, the values of penetration resistance under respective treatments were 11.8 and 7.7 $\mathrm{kg} / \mathrm{cm}$, similarly Tharmaraj et al., (2011) reported that soil application of vermicompost and spray of vermiwash improved physical (water holding capacity, porosity and moisture content), chemical properties $(\mathrm{pH}$ and EC) as well as soil fertility (N, P, K, Ca and $\mathrm{Mg}$ ) over control and its individual application. Effect of integrated nutrient management on soil fertility management on soil fertility were studied by Naidu et al., (2009) and results revealed that highest status of major and micronutrients in soil in the treatment, 50\% RDN+50\% N through FYM + BF + Panchagavya @ 3\% foliar spray similar results were obtained by Ansari and Kumar (2010) i.e. the significantly higher content of organic $\mathrm{C}$ in the treatment of vermiwash + vermicompost followed by only vermicompost and only cowdung (100 $\mathrm{g} /$ plant). However, higher content of N, P, K, $\mathrm{Ca}, \mathrm{Mg}, \mathrm{Fe}, \mathrm{Mn}, \mathrm{Zn}$ and $\mathrm{Cu}$ were observed in the chemical fertilizer treatment followed by treatments of vermiwash + vermicompost. Ramesh et al., (2010) surveyed the certified organic farm of Maharashtra, Karnataka, Tamil Nadu, Kerala, Uttarakhand to ascertain the real benefits and feasibility of organic farming in terms of the production potential, economics and soil health in comparison to the conventional farms. The survey result revealed that there was an all over improvement in soil quality in terms of physical, chemical, fertility and biological properties of soil. 
With all the study were concluded that the organic nutrients which significantly increases the crop growth, yield, quality and soil qualities in better manner and which significantly reflects on the soil microorganism and soil enzymes.

\section{References}

Abraham, T. and Lal, R. B. (2003). Enhancement of productivity potential of greengram (Vigna radiata L.) through integrated nutrient management (INM) in a legume based cropping system. Madras Agricultural Journal, 90 (7-9): 431-437.

Anonymous (2011b). RKVY project, Navsari Agricultural University, Navsari.

Ansari, A. A. and Kumar, S. (2010). Effect of vermiwash and vermicompost on soil parameters and productivity of okra (Abelmoschus esculentus) in Guyana. Current Advances in Agricultural Sciences, 2 (1): 1-4.

Bais, R. C., Burghate, S. K., Deshmukh, P. A. and Bonde, A. S. (2010). Effect of foliar application of animal urine and panchagavya on auxin content and IAA oxidase enzyme activity in desi cotton. Crop Research, 40 (1, 2 and 3): 192 196.

Bindumathi, M. (2008). Evaluation of organic growth promoters on yield of dryland vegetable crops in India. Journal of Organic Systems, 3 (1): 23-36.

Devakumar. N., Rao, G. G. E., Shubha, S., Imrankhan, Nagaraj and Gowda, S. B., 2008, Activities of Organic Farming Research Centre, Navile, Shimoga, Univ. Agric. Sci., Bengaluru, Karnataka, India.

George, S., Giraddi, R.S. and Patil, R.H. (2007). Utility of vermiwash for the management of thrips and mites on chilli (Capsicum annuum L.) amended with soil organics. Karnataka Journal of Agriculture Science, 20 (3): 657-659.

Jayathilake, P. K. S., Reddy, I. P., Srihari, D., Neeraja, G. and Reddy, R. (2002). Effect of nutrient management on growth, yield and yield attributes of rabi onion (Allium cepa L.). Vegetable Science, 29 (2): 184-185.

Kagne, S. V., Bavalgave, V. G., Waghmare, M. S. and Bodake, B. L. (2008). Response of fertilizers and organic manure on growth, yield and quality of sweet sorghum. Asian Journal of Soil Science, 3 (2): 313-315.

Kumar, S. G., Muthukrishnan, P., Ramasamy, S. and Chandragiri, K. K. (2008). Effect of organic and inorganic foliar spray on growth and yield of blackgram (Vigna mungo L.). Madras Agricultural Journal, 95 (1-6): 57-60.

Nagarajan, M., Rajasekaran, S., Ganesh, K. S. (2013). Antibacterial Activity of Lawsonia inermis L. International Journal of Modern Biology and Medicine, 4(3): 169-175.

Naidu, K.D., Radder, B.M., Patil, P.L., Hebsur, N.S. and Alagundagi, S.C. (2009). Nutrient uptake and residual fertility of chilli ( $\mathrm{Cv}$. byadgi dabbi) in a Vertisols. Karnataka Journal of Agriculturel Science, 22 (2): 306-309.

Natarajan K. (2008). Panchagavya - A manual. Other India Press, Mapusa, Goa, India PP. 33

Paramasivam, V., Balamurugan, P. and Mohandas, S. (2006). Influence of organic sources of nutrients on seed quality characteristics of groundnut. Madras Agricultural Journal, 93 (1-6): 125-128.

Patil, K. D., Ranjun, A. R., Waghdhare, S. and Patil, S. R. (2008). Effect of conjoint use of manures and fertilizers on yield and quality of soybean grains. Asian Journal of Soil Science, 3 (1): 47. 
Priya, R. K., Srivastava, S., Singh, K. K., Mathad, C. and Thind, P. S. (2014). Study of Antioxidant and Antimicrobial Properties, Phytochemical screening and analysis of Sap Extracted from Banana (Musa acuminata) pseudostem. International Journal of Advanced Biotechnology and Research, 5(4): 649658. http://www.bipublication.com.

Ramesh, P., Panwar, N. R., Singh, A. B., Ramana, S., Yadav, S. K., Shrivastava, R. and Rao, A. S. (2010). Status of organic farming in India. Current Science, 98 (9): 1190-1194.

Ramprasad, V., Srikanthamurthy, H. S., Ningappa Kakol, Shivakumar, Nagaraju, B., NINGARAJU, Shashidhara, Doddappa, Vijay, A. R., Shivanna, M. Obanna, N. Pandu, A. C., Rama Satish, Sandhya, M. and Veena P., (2009). Sustainable Agricultural Practices. Green Foundation Bangalore, First edition, India.

Ravichandran, G., Natarajan, N., Manorama, K. and Vanangamudi, K. (2011). Effect of organic sprays on storage behavior of seed potatoes. Indian Journal of Horticulture, 68(3): 399-407.

Salunkhe, J.R. (2010) Feasibility of using banana pseudostem sap as liquid fertilizer in onion under drip irrigation. M.Sc. thesis Navsari Agricultural university. (N.A.U.) Navsari.

Sampath Kumar. K. P., DebjitBhowmik, S. Duraivel and M. Umadevi. (2012). Traditional and Medicinal Uses of Banana. Journal of Pharmacognosy and Phytochemistry, 1(3).

Sanjutha, S.S., Subramanian, C., Indu Rani, J. and Maheswari (2008). Integrated nutrient management in Andrographis paniculata. Research Journal of Agriculture and Biological Sciences, 4(2): 141-145.

Sathish, G. and Paramaguru, P. (2010). Response of bioregulants on nutrient uptake pattern of turmeric (Curcuma longa L.) cv. BSR 2. Madras Agricultural Journal, 97 (10-12): 312314.

Shashidhara, G. B, 2000, Integrated nutrient management in chilli (Capsicum annuum L.) under Northern Transitional Zone of Karnataka. Ph.D. Thesis (Unpub.), Univ. Agric. Sci., Dharwad, Karnataka, India.

Sivasubramanian, K. and Ganeshkumar, M. (2004). Influence on vermiwash on the biological productivity of marigold. Madras Agricultural Journal, 91 (4-6): 221-225.

Somasundaram, E., Amanullah, M. M., Thirukkumaran, K., Chandrasekaran, R., Vaiyapuri, K. and Sathyamoorthi, K. (2007). Biochemical changes, nitrogen flux and yield of crops due to organic sources of nutrients under maize based cropping system. Journal of Applied Sciences Research, 3(12): 1724-1729.

Somasundaram, E., Sankaran, N., Meena, S., Thiyagarajan, T. M., Chandragiri, K. K. and Panneerselvam, S. (2003). Response of greengram to varied concentrations of panchakavya (organic nutrition) foliar application. Madras Agricultural Journal, 90 (1-3): 169-172.

Sritharan, N., Rajavel, M. and Chandrasekhar, C. N. (2010). Impact of bioregullators on phytochemical and quality of black night shade Solanum nigrum. Madras Agricultural Journal, 97 (4-6): 93-96.

Surekha, K., Jhansilakshmi, V., Somasekhar, N., Latha, P. C., Kumar, R. M., Shobharani, N., Rao, K. V. and Viraktamath, B. C. (2009). Status of organic farming and research experiences in rice. Journal of Rice Research, 3(1): 23-35.

Thanunathan, K., Natarajan. S., Senthilkumar. R. and Arulmurugan, K. (1997). Effect of different sources of organic amendments on growth and yield of 
onion in mine soil. Madras Agricultural Journal, 84(7): 382-384.

Tharmaraj, K., Ganesh. P., Kolanjinathan. K., Suresh Kumar. R. and Anandan A. (2011) Influence of vermicompost and vermiwash on physico chemical properties of rice cultivated soil. Current Botany, 2(3): 18-21.

Venkatalakshmi, K., Balasubramanian, A. and Sankaran N. (2009). Influence of seed treatment and foliar spray of panchagavya on growth, yield attributes and yield of Amaranthus viride. Madras Agriculture Journal, 96 (1-6): 135-138.

Venkataramana, P.B., Narasimha Murthy, Krishna Rao, J.V. and Kamble. C.K. (2010). Efficacy of foliar sprays of vermi wash and cow dung wash on biochemical and yield attributes and yield of mulberry (Morus alba L.).
Karnataka Journal of Agriculture Science, 23(2): 358-360.

Vennila, C. and Jayanthi, C. (2010). Effect of inorganic nutrients and organic foliar spray on growth and yield of okra. Progressive Horticulture, 42 (1): 94-96.

Virdia, H. M., Mehta, H. D. and Parmar, V. N. (2011). Effect of organics on paddycastor cropping system. Green Farming, 2(3): 298-301.

Yadav, B.K. and Christopher L. (2006) Effect of organic manures and Panchagavya spray on yield attributes, yield and economics of rice. Crop Research, 31(1): 1-5.

Zalate, P. Y. and Padmani, D. R. (2010). Quality and nutrient uptake pattern of groundnut (Arachis hypogea, L.) as influenced by integrated nutrient management. GAU Research Journal, 35(2): 94-96.

\section{How to cite this article:}

Santosh Onte, Magan Singh, Sanjeev Kumar and Prasanna S. Pyati. 2019. Impact of Organic Nutrient Management on Crop Quality, Yield and Soil Health: A Review. Int.J.Curr.Microbiol.App.Sci. 8(05): 394-402. doi: https://doi.org/10.20546/ijcmas.2019.805.047 